University of Nebraska - Lincoln

DigitalCommons@University of Nebraska - Lincoln

Agronomy \& Horticulture -- Faculty Publications

Agronomy and Horticulture Department

2008

Determining optimum planting dates for pearl millet for two contrasting environments using a modelling approach

\author{
C. M. T. Soler
}

N. Maman

X. Zhang

S. C. Mason

University of Nebraska-Lincoln, smason1@unl.edu

G. Hoogenboom

University of Nebraska-Lincoln

Follow this and additional works at: https://digitalcommons.unl.edu/agronomyfacpub

Part of the Plant Sciences Commons

Soler, C. M. T.; Maman, N.; Zhang, X.; Mason, S. C.; and Hoogenboom, G., "Determining optimum planting dates for pearl millet for two contrasting environments using a modelling approach" (2008). Agronomy \& Horticulture -- Faculty Publications. 363.

https://digitalcommons.unl.edu/agronomyfacpub/363

This Article is brought to you for free and open access by the Agronomy and Horticulture Department at DigitalCommons@University of Nebraska - Lincoln. It has been accepted for inclusion in Agronomy \& Horticulture -Faculty Publications by an authorized administrator of DigitalCommons@University of Nebraska - Lincoln. 


\title{
Determining optimum planting dates for pearl millet for two contrasting environments using a modelling approach
}

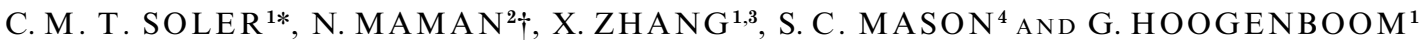 \\ ${ }^{1}$ Department of Biological and Agricultural Engineering, The University of Georgia, 1109 Experiment Street, \\ Griffin, GA 30223-1797, USA \\ ${ }^{2}$ Institut National de Recherches Agronomiques du Niger, B.P. 429, Niamey, Niger \\ ${ }^{3}$ Institute of Geographic Science and Natural Resources, Chinese Academy of Sciences, P.O. Box 9717 , \\ Beijing 100101, P.R. China \\ ${ }^{4}$ Department of Agronomy, University of Nebraska, Lincoln, NE 68583-0915, USA \\ (Revised MS received 9 October 2007; First published online 14 January 2008)
}

\begin{abstract}
SUMMARY
Pearl millet [Pennisetum glaucum (L) R. Br.] is an important cereal crop in Niger, West Africa and a potential crop for the United States of America (USA). Only a few studies have been conducted in either country to identify the optimum planting dates for high and stable yields, in part because planting date experiments are resource-intensive. Crop simulation models can be an alternative research tool for determining optimum planting dates and other management practices. The objectives of the present study were to evaluate the performance of the Cropping System Simulation Model (CSM)-CERES-Millet model for two contrasting environments, including Mead, Nebraska, USA and Kollo, Niger, West Africa and to use the model for determining the optimum planting dates for these two environments. Field experiments were conducted in both environments to study the impact of nitrogen fertilizer on grain yield of three varieties in Kollo and three hybrids in Mead and their associated growth and development characteristics. The CSM-CERES-Millet model was able to accurately simulate growth, development and yield for millet grown in these two contrasting environments and under different management practices that included several genotypes and different nitrogen fertilizer application rates. For Kollo, the optimum planting date to obtain the maximum yield was between 13 and 23 May for variety Heini Kirei, while for the other varieties the planting dates were between 23 May and 2 June. For Mead, the planting date analysis showed that the highest simulated yield was obtained, on average, between 19 and 29 June for hybrid 59022A $\times 89-083$ and $1361 \mathrm{M} \times 6 \mathrm{Rm}$. Further studies should focus on evaluation and application of the millet model for other agroclimatic regions where pearl millet is an important crop.
\end{abstract}

\section{INTRODUCTION}

Pearl millet [Pennisetum glaucum (L) R. Br.] is an important tropical food cereal grown on approximately 26 million ha in semi-arid regions, including West and South Africa and India (Andrews et al. 1993; Andrews \& Bramel-Cox 1994). In Niger, pearl millet is the main staple food and is the dominant crop in the agricultural production systems,

* To whom all correspondence should be addressed. Email: ctojo@uga.edu

$\uparrow$ Present address: INTSORMIL - INTARNA Research Station, B.P. 429, Maradi, Niger. contributing about 0.75 of the national total cereal production (Amadou et al. 1999; FAOSTAT data 2005). Pearl millet productivity is usually low (300-550kg/ha) (Graef \& Haigis 2001) and variable (Rockstrom et al. 1999), in part because of natural causes, including a short rainy season that is spatially and temporally variable (Graef \& Haigis 2001) and poor soil quality. In Niger, the length of the growing period is mainly a function of the date of the first rains (Sivakumar 1988) and varies widely from year to year. However, due to the erratic rainfall pattern in the Sahelian regions, the first rain suitable for planting is often followed by several dry days that cause 
the planting to fail and require the farmers to replant. According to Bationo et al. (1990) and Bationo \& Ntare (2000), during normal or above normal rainfall years, grain yield for pearl millet could be improved by increasing the plant population and $\mathrm{N}$ fertilizer applications; but yield could slightly decrease during drought years. However, Maman et al. (2000) and Kathju et al. (2001) found that even in drier years, a high plant population and fertilizer applications were necessary to obtain higher yields. Bacci et al. (1999), in a study conducted in Mali, West Africa, evaluated two planting dates; the first planting coincided with the beginning of the rainy season and the second planting was 20 days later. The two planting dates did not show any statistical differences in yield.

The area planted with pearl millet in the United States of America (USA) is about 241000 ha (FAOSTAT data 2005). It is grown primarily as a forage crop, although some grain production occurs in the Southeast as a result of the development of adapted hybrids (Hanna 1995) and recognition of the high feeding value of pearl millet grain by the poultry industry (Amato \& Forrester 1995; Andrews et al. 1996). Some pearl millet has also been grown for birdseed. In the USA, the planting date for millet is defined by a minimum threshold for soil temperature (Andrews et al. 1998). Planting pearl millet in early June when soil temperatures are above $18{ }^{\circ} \mathrm{C}$ is recommended (Andrews et al. 1998), although the minimum temperature for growth is $12{ }^{\circ} \mathrm{C}$ (Ong \& Monteith 1985). Results of experiments conducted in Nebraska showed that the best planting dates for pearl millet were between 7 June and 6 July, suggesting that pearl millet could be an alternative crop for double cropping and/or late replanting situations in Nebraska (Pale et al. 2003).

Crop simulation models can be useful tools for the evaluation of alternative management options for a particular location, including fertilizer application rates, planting density, planting dates and others (Tsuji et al. 1998; Ruiz-Nogueira et al. 2001; Saseendran et al. 2005). The Decision Support System for Agrotechnology Transfer (DSSAT) is a comprehensive decision support system for assessing management options (Tsuji et al. 1994; Jones et al. 2003; Hoogenboom et al. 2004). The Cropping System Simulation Model (CSM), which is the main crop simulation model that encompasses DSSAT version 4.0 (Jones et al. 2003; Hoogenboom et al. 2004), is a process-oriented, dynamic crop simulation model that simulates crop growth, development and yield for 27 food and other crops, including pearl millet. Crop growth is simulated with a daily time step, starting at planting until harvest maturity is reached, based on physiological processes that describe the crop's response to soil and weather conditions. Potential growth is dependent on the interception of photosynthetically active radiation, whereas actual biomass production on any day is constrained by a suboptimal temperature, soil water deficit and nitrogen deficiency. The input data required to run the DSSAT models include daily weather data (maximum and minimum temperature, rainfall and solar radiation); soil characterization data (by soil layer); a set of cultivar coefficients characterizing the variety being grown; and crop management information, such as emerged plant population, row spacing, seeding depth and fertilizer and irrigation schedules. A detailed description of the CERES-Millet model, the predecessor of the CSM-CERES-Millet, is provided by Ritchie \& Alagarswamy (1989) and Ritchie et al. (1998). Fechter et al. (1991) conducted an evaluation of the CSM-CERES-Millet model for south-west Niger, while Thornton et al. (1997) used the model for estimating millet production in Burkina Faso. The CSM-CERES-Millet was also evaluated for four regions in Niger by Ravelo \& Planchuelo (1993); the model predicted growth and development accurately, while the yield estimates had an average relative error of $0 \cdot 07$. Although these studies are considered very valuable, the evaluation of the CSM-CERES-Millet model for different regions of the world has been minimal compared to other crop models. This reflects the need for further modelling studies, especially pearl millet, as it is such an important crop for resource-poor farmers, especially in the semi-arid tropics where environmental conditions for crops are harsh. The goal of the present study was to evaluate the performance of the CSM-CERESMillet model for two contrasting environments, including Mead, Nebraska, USA and Kollo, Niger, West Africa and to determine the optimum planting dates for these two environments using a modelling approach.

\section{MATERIALS AND METHODS}

\section{Experimental data}

The CSM-CERES-Millet model of the DSSAT Version 4.0 (Jones et al. 2003; Hoogenboom et al. 2004) was evaluated with experimental data that were collected in Kollo, Niger and Nebraska, USA. For Niger, the observed data were obtained from two experiments conducted in Kollo in 1995 and 1996 (Maman et al. 2000). The experimental treatments consisted of a factorial combination of three pearl millet varieties with two levels of management based on plant population and nitrogen fertilizer rate, in a randomized complete block design with three replicates. The varieties were: Heini Kirei (a local land race variety, 2.8-3.0 m tall, with a maturity classification of 110-115 days to physiological maturity), Zatib (an improved variety, $1 \cdot 8-2.0 \mathrm{~m}$ tall, with a maturity classification of 95-105 days) and 3/4 HK (an improved dwarf variety, $0 \cdot 8-1 \cdot 2 \mathrm{~m}$ tall, with a 
Table 1. Cultivar coefficients for the three varieties grown in Kollo, Niger and for the three hybrids grown in Mead, Nebraska

\begin{tabular}{|c|c|c|c|c|c|c|}
\hline \multirow[b]{2}{*}{ Cultivar coefficient } & \multicolumn{3}{|c|}{ Varieties grown in Kollo } & \multicolumn{3}{|c|}{ Hybrids grown in Mead } \\
\hline & $\begin{array}{l}\text { Heini } \\
\text { Kirei }\end{array}$ & Zatib & $3 / 4 \mathrm{HK}$ & $\begin{array}{l}59022 \mathrm{~A} \times \\
89-083\end{array}$ & $\begin{array}{c}1011 \mathrm{~A} \times \\
086 \mathrm{R}\end{array}$ & $\begin{array}{l}1361 \mathrm{M} \times \\
6 \mathrm{Rm}\end{array}$ \\
\hline $\begin{array}{l}\mathrm{P} 1 \text { - Thermal time from seedling emergence to } \\
\text { the end of the juvenile phase (expressed in degree } \\
\text { days above a base temperature of } 10^{\circ} \mathrm{C} \text { ) during } \\
\text { which the plant is not responsive to changes in } \\
\text { photoperiod. }\end{array}$ & 396 & 309 & 270 & 100 & 100 & 100 \\
\hline $\begin{array}{l}\text { P20 - Critical photoperiod or the longest day } \\
\text { length (in hours) at which development occurs } \\
\text { at a maximum rate. At values greater than P20, } \\
\text { the rate of development is reduced. }\end{array}$ & 12 & 12 & 12 & 12 & 12 & 12 \\
\hline $\begin{array}{l}\mathrm{P} 2 \mathrm{R} \text { - Extent to which the phasic development } \\
\text { leading to panicle initiation (expressed in degree } \\
\text { days) is delayed for each hour increase in } \\
\text { photoperiod above P20. }\end{array}$ & 470 & 410 & 390 & 18 & 35 & 55 \\
\hline $\begin{array}{l}\text { P5 - Thermal time (degree days above a base } \\
\text { temperature of } 10^{\circ} \mathrm{C} \text { ) from beginning of grain } \\
\text { filling ( } 3-4 \text { days after flowering) to physiological } \\
\text { maturity. }\end{array}$ & 140 & 108 & 108 & 200 & 120 & 105 \\
\hline G1 - Scaler for relative leaf size. & $0 \cdot 5$ & $0 \cdot 5$ & $0 \cdot 5$ & 0 & 0 & 0 \\
\hline $\begin{array}{l}\text { G4 - Scaler for partitioning of assimilates to the } \\
\text { panicle (head). }\end{array}$ & 11 & 13 & 18 & 19 & 17 & 11 \\
\hline
\end{tabular}

maturity classification of 85-95 days). The two management factors were: (a) traditional, with a low plant population (30000 plants/ha) and without fertilizers and (b) enhanced, with an increased plant population (60000 plants/ha) and $23 \mathrm{~kg} / \mathrm{ha}$ of $\mathrm{N}$. The planting dates were 12 June 1995 and 26 June 1996.

Daily weather records for the site were obtained from the International Crop Research Institute for the Semi-Arid Tropics (ICRISAT) at Kollo, latitude $13 \cdot 23 \mathrm{~N}$; longitude $2 \cdot 28 \mathrm{E}$; elevation $210 \mathrm{~m}$. The soil at the experimental site was a Pasammentic Paleustalf with a sandy texture and $\mathrm{pH}$ of $4 \cdot 9$.

For Nebraska, the experimental data for model evaluation were obtained from two experiments conducted at the University of Nebraska near Mead under rainfed conditions in 1995 and 1996. The experiment was conducted in a randomized complete block design with four replicates and the treatments consisted of factorial combinations of three dwarf pearl millet hybrids with two levels of management based on fertilizer rates of 0 and $78 \mathrm{~kg} / \mathrm{ha}$ of $\mathrm{N}$. The three pearl millet hybrids (and their maturity classifications) were $59022 \mathrm{~A} \times 89-083$ (60-62 days to flowering), $1011 \mathrm{~A} \times 086 \mathrm{R}$ (66-68 days to flowering), and $1361 \mathrm{M} \times 6 \mathrm{Rm}(72-74$ days to flowering; Maman et al. 1999). Pearl millet was planted on 19 June for the experiment conducted in 1995 and on 13 June for the experiment conducted in 1996. The plant population at emergence was 98700 plants/ha in 1995 and 114900 plants/ha in 1996.

Daily weather records were obtained from an automated weather station located at Mead, Nebraska (latitude $41 \cdot 25 \mathrm{~N}$; longitude $96 \cdot 58 \mathrm{~W}$; elevation $366 \mathrm{~m}$ ). The soil at the experimental site was a Sharpsburg silty clay loam (fine, smectitic and, mesic Typic Argiudoll) with a $\mathrm{pH}$ of $6 \cdot 0$.

\section{Model evaluation}

The CSM-CERES-Millet model includes seven cultivar-specific coefficients that require modification for new cultivars that have not been used previously with the crop model. Six specific cultivar coefficients were adjusted for pearl millet during the evaluation process (Table 1). These cultivar coefficients were determined in sequence, starting with the phenological development coefficients and followed by the crop growth coefficients. This order was required because of the dependence of the latter coefficients on the performance of the vegetative and reproductive development simulations (Jones et al. 1987; Hoogenboom et al. 1992). An iterative procedure (Hunt et al. 1993) was used to select the most appropriate value for each phenological and development coefficient. Emergence, flowering, maturity dates, growth analysis data and yield were used to evaluate the performance of the 
model. However, for Kollo, flowering and maturity dates were only available for 1995 and for Mead, Nebraska only for 1996. The combination of coefficients that resulted in the highest Index of Agreement (d) (Eqn 1) and the smallest root mean square error (RMSE) (Eqn 2) between observed and simulated values were selected as the final cultivar coefficients. According to the $d$-statistic (Willmott et al. 1985), the closer the index value approaches one, the better the agreement between the two variables that are being compared and vice versa.

$$
d=1-\left[\frac{\sum_{i=1}^{n}(\mathrm{Pi}-\mathrm{Oi})^{2}}{\sum_{i=\mathbf{1}}^{n}\left(\left|\mathrm{P}^{\prime} \mathrm{i}\right|+\left|\mathrm{O}^{\prime} \mathrm{i}\right|\right)^{2}}\right]
$$

where $n$ is the number of observations, $\mathrm{Pi}$ is a predicted observation, $\mathrm{Oi}$ is a measured observation, $\mathrm{P}^{\prime} \mathrm{i}=\mathrm{Pi}-M$ and $\mathrm{O}^{\prime} \mathrm{i}=\mathrm{Oi}-M(M$ is the average of the observed variable).

The RMSE was calculated according to Loague \& Green (1991):

$$
\mathrm{RMSE}=\sqrt{\frac{\sum_{i=1}^{n}(\mathrm{Pi}-\mathrm{Oi})^{2}}{n}}
$$

where Pi and Oi refers to the predicted and observed variables.

\section{Optimum planting dates}

A planting date analysis was conducted using 20 years of climate records for Kollo and 35 years of climate records for Mead. In this analysis, the effects of varying planting dates on millet yield were studied. For Kollo, 12 planting dates were simulated beginning on 24 March for every 10 days until 12 July. For Mead, 12 planting dates were simulated beginning on 10 April for every 10 days until 29 July. The simulated yields for the different planting dates were analysed using the ANOVA Procedure of SAS (SAS Institute 2001). The means were compared with Tukey's test, with a significance level of $P \leqslant 0 \cdot 05$. Simulated yield and cumulative total evapotranspiration for the entire growing season were analysed for each individual planting date. A regression analysis was also performed to identify the relation between simulated evapotranspiration and simulated grain yield.

\section{RESULTS}

\section{Weather conditions for Kollo, Niger}

Niger's climate is mainly hot and dry, with much desert area. However, in the extreme south there is a tropical climate on the edges of the Niger River basin. The average monthly maximum temperatures for 20 years, i.e. $1982-2001$, were always greater than $32^{\circ} \mathrm{C}$ and the average monthly minimum temperatures were always greater than $18.5^{\circ} \mathrm{C}(\mathrm{Fig}$. $1 a$ ). The rainy season, on average, started in April and ended in September, with a maximum precipitation of $150 \mathrm{~mm}$ in July. The 1995 and 1996 growing seasons showed a similar amount of precipitation as the average for 20 years (1982-2001). For the 1995 growing season, total precipitation was $448 \mathrm{~mm}$ with 32 rainy days and for the 1996 the total precipitation was $423 \mathrm{~mm}$ with 26 rainy days (Fig. $2 a$ ).

\section{Weather conditions for Mead, Nebraska}

In Mead, the summers are hot and humid with intense summer convectional storms, while small quantities of precipitation occur during the winter. The analysis of the series of 35 years (1969-2003) of weather records for Mead, showed that the highest maximum and minimum average monthly temperatures occurred in July ( 31 and $17 \cdot 8{ }^{\circ} \mathrm{C}$, respectively), while the maximum solar radiation occurred in June (Fig. $1 b$ ). With respect to precipitation, the highest monthly values were observed between April and October, with a maximum for May $(110 \mathrm{~mm})$.

For Mead, the rainfall was below the 30-year longterm average during the 2 years in which the experiments were conducted. However, the 1996 growing season in Mead was characterized by a higher amount of rainfall $(257 \mathrm{~mm})$ than the 1995 growing season $(145 \mathrm{~mm}$; Fig. $2 b)$. The number of rainy days for the two growing seasons was similar, i.e. 25 for 1995 and 26 for 1996.

\section{Evaluation of the CSM-CERES-Millet model for Kollo, Niger}

For the varieties grown in the field experiments conducted in Kollo, there were no differences for the cultivar coefficients P20 and G1, while the other cultivar coefficients were different between varieties (Table 1). The values for cultivar coefficient P2R (extent to which the phasic development leading to panicle initiation, expressed in degree days, is delayed for each hour increase in photoperiod above P20), were important. The value of P2R for Heini Kirei was 470 degree days, while the values for Zatib and $3 / 4 \mathrm{HK}$ were 410 and 390 degree days, respectively. The cultivar coefficient P5, thermal time from beginning of grain filling to physiological maturity above a base temperature of $10^{\circ} \mathrm{C}$, was 108 degree days for Zatib and 3/4HK and 140 degree days for Heini Kirei.

The observed and simulated numbers of days from planting to anthesis were identical for each one of the three varieties (Table 2). The simulated number of days from planting to physiological maturity was similar to the observed number of days to physiological maturity, indicating that the phenology of millet was very accurately predicted by the CSMCERES-Millet model. The variety Heini Kirei had 

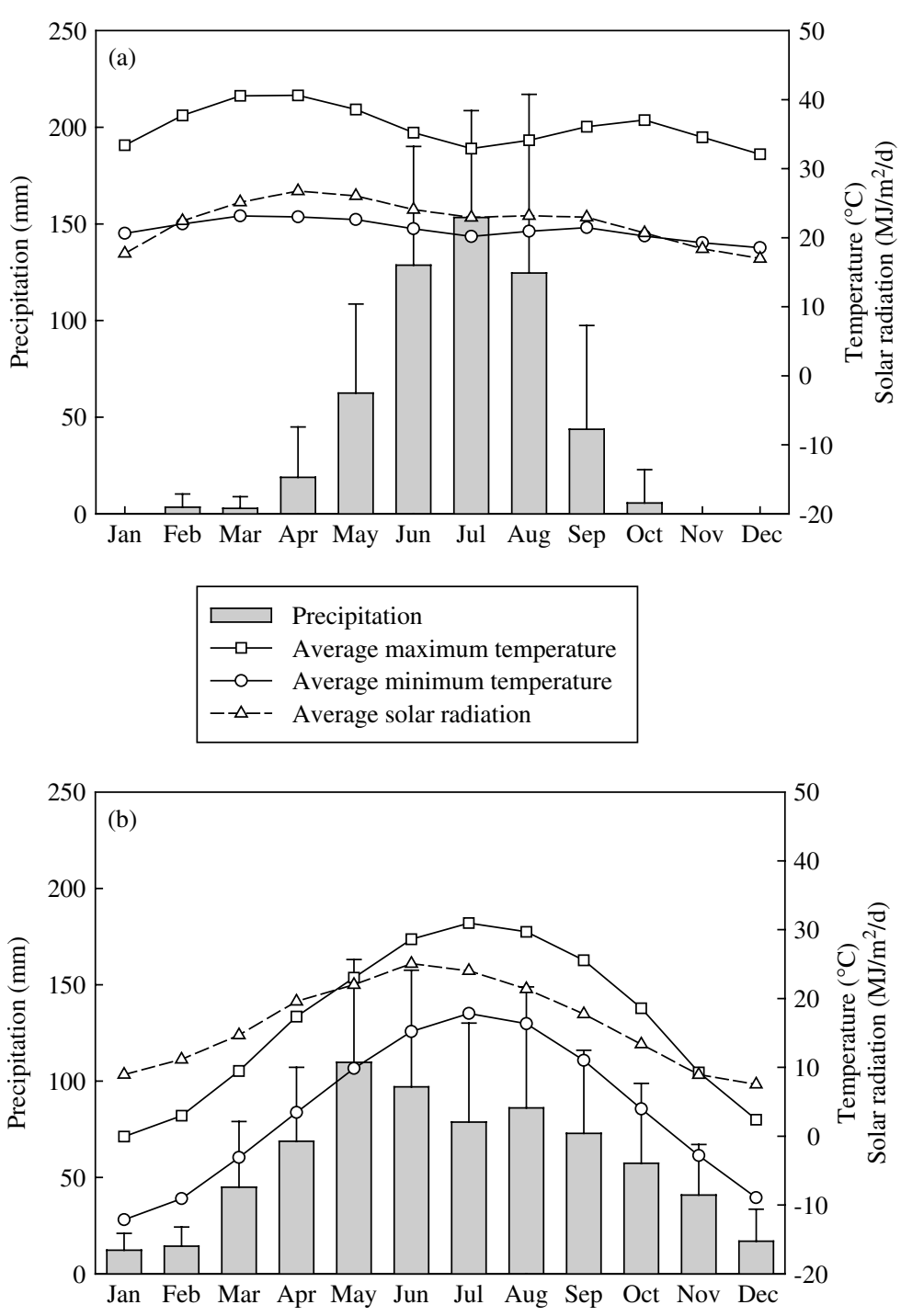

$$
\begin{aligned}
& \square \text { Precipitation } \\
& \square-\text { Average maximum temperature } \\
& \multimap-\text { Average minimum temperature } \\
& --\triangle-\text { Average solar radiation }
\end{aligned}
$$

Fig. 1. Average monthly precipitation, average maximum and minimum temperature, and average solar radiation for Kollo, Niger for 1982-2001 (a) and for Mead, Nebraska, USA for 1969-2003 (b).

the longest duration from planting to physiological maturity (116 days) of the three varieties.

The average observed yield for the three varieties was $1130 \mathrm{~kg} / \mathrm{ha}$ and the corresponding average simulated yield was $992 \mathrm{~kg} /$ ha for 1995 (Fig. $3 a$ ). The average observed yield for the three varieties for 1996 decreased $50 \%$ when compared to the average observed yield obtained for 1995. For 1996, the average observed and simulated yield values were very similar, 547 and $354 \mathrm{~kg} / \mathrm{ha}$, respectively (Fig. 3 b). The average observed yield for three varieties for the 2 years was $838 \mathrm{~kg} / \mathrm{ha}$, while the average simulated yield value corresponded to $673 \mathrm{~kg} / \mathrm{ha}$. The RMSE for all three varieties for the 2 years of experiments 
Table 2. Observed and simulated days to anthesis and physiological maturity for the three varieties grown in Kollo for 1995 and for the three hybrids grown in Mead, Nebraska for 1996

\begin{tabular}{|c|c|c|c|}
\hline & & Observed & Simulated \\
\hline \multicolumn{4}{|c|}{ Varieties grown in Kollo } \\
\hline \multirow[t]{2}{*}{ Heini Kirei } & Planting to anthesis (days) & 97 & 97 \\
\hline & Planting to physiological maturity (days) & 116 & 116 \\
\hline \multirow{2}{*}{ Zatib } & Planting to anthesis (days) & 88 & 88 \\
\hline & Planting to physiological maturity (days) & 104 & 106 \\
\hline \multirow[t]{2}{*}{$3 / 4 \mathrm{HK}$} & Planting to anthesis (days) & 84 & 84 \\
\hline & Planting to physiological maturity (days) & 100 & 101 \\
\hline \multicolumn{4}{|c|}{ Hybrids grown in Mead } \\
\hline \multirow[t]{2}{*}{$59022 \mathrm{~A} \times 89-083$} & Planting to anthesis (days) & 55 & 55 \\
\hline & Planting to physiological maturity (days) & 90 & 90 \\
\hline \multirow[t]{2}{*}{$1011 \mathrm{~A} \times 086 \mathrm{R}$} & Planting to anthesis (days) & 62 & 62 \\
\hline & Planting to physiological maturity (days) & 90 & 90 \\
\hline \multirow[t]{2}{*}{$1361 \mathrm{M} \times 6 \mathrm{Rm}$} & Planting to anthesis (days) & 70 & 70 \\
\hline & Planting to physiological maturity (days) & 104 & 104 \\
\hline
\end{tabular}
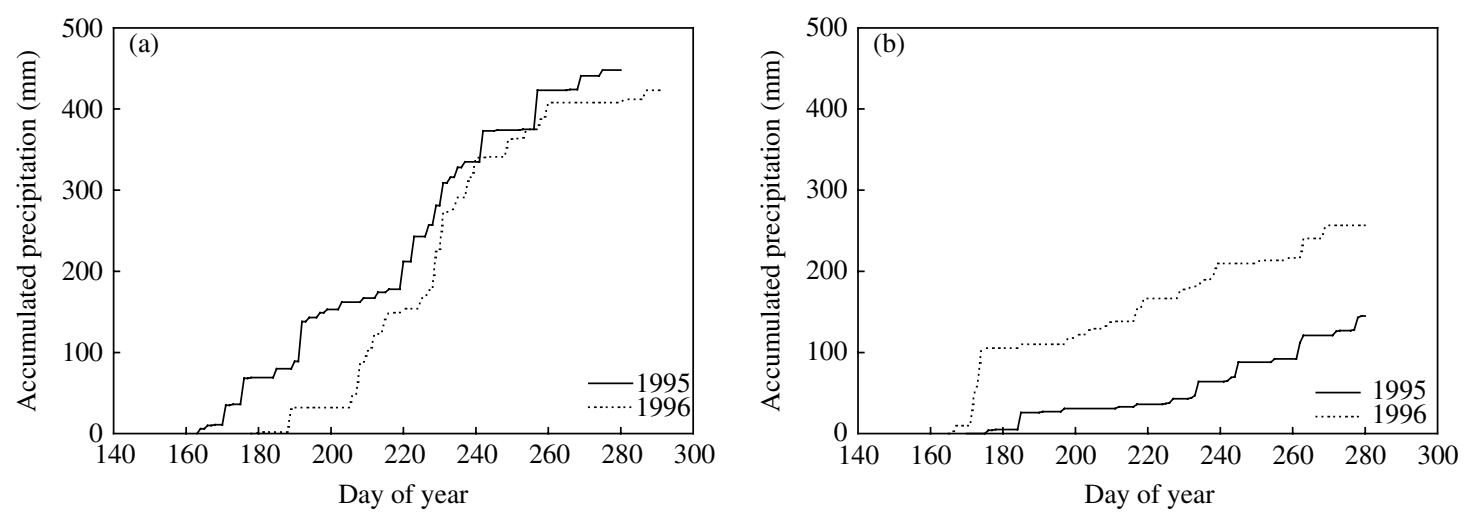

Fig. 2. Total precipitation for 1995 and 1996 for Kollo (a) and for Mead (b) as a function of day of year.

was $429 \mathrm{~kg} / \mathrm{ha}$ and the $d$ value was $0 \cdot 83$. In addition, the above ground biomass at harvest was accurately simulated and the value for $d$ was 0.90 for all three varieties for both years.

\section{Evaluation of the CSM-CERES-Millet model for Mead, Nebraska}

For the hybrids grown in Mead, Nebraska, the cultivar coefficient $\mathrm{P} 1$ that corresponds to the thermal time from seedling emergence to the end of the juvenile phase (expressed in degree days above a base temperature of $10^{\circ} \mathrm{C}$ ) during which the plant is not responsive to changes in photoperiod was set to 100 (Table 1). The cultivar coefficient P2R (extent to which the phasic development leading to panicle initiation is delayed for each hour increase in photoperiod above P20) was 18 degree days for the hybrid $59022 \mathrm{~A} \times 89-083,35$ for the hybrid $1011 \mathrm{~A} \times 086 \mathrm{R}$ and 55 for the hybrid $1361 \mathrm{M} \times 6 \mathrm{Rm}$. The cultivar coefficient P5 (thermal time from beginning of grain filling to physiological maturity above a base temperature of $10^{\circ} \mathrm{C}$ ) varied between 105 degree days for hybrid $1361 \mathrm{M} \times 6 \mathrm{Rm}$ and 200 for hybrid $59022 \mathrm{~A} \times$ 89-083.

The CSM-CERES-Millet model was able to accurately simulate the number of days from planting to anthesis and from planting to physiological maturity for the three pearl millet hybrids grown in Mead, Nebraska during the 1996 growing season (Table 2). The observed number of days from planting to anthesis were 55, 62 and 70 days for the hybrids $59022 \mathrm{~A} \times 89-083,1011 \mathrm{~A} \times 086 \mathrm{R}$ and $1361 \mathrm{M} \times 6 \mathrm{Rm}$, respectively. The total period from planting to physiological maturity was 90 days for the hybrids $59022 \mathrm{~A} \times 89-083$ and $1011 \mathrm{~A} \times 086 \mathrm{R}$ and 104 days for the hybrid $1361 \mathrm{M} \times 6 \mathrm{Rm}$. The simulated values from planting to physiological maturity were similar to the observed values for this period for the three hybrids as shown in Table 2. 

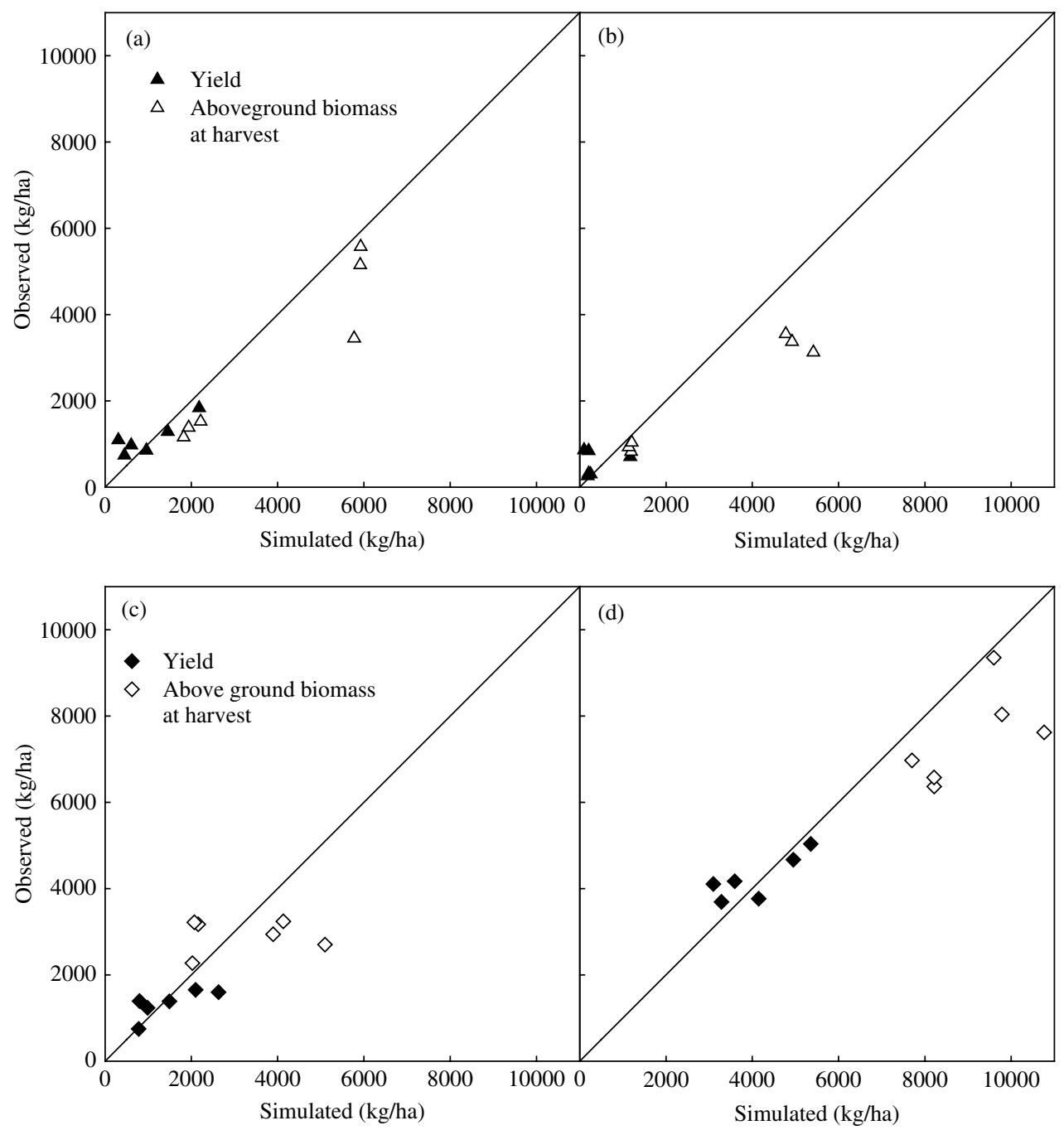

Fig. 3. Simulated and observed yield and biomass at harvest for Kollo for the years 1995 (a) and 1996 (b) and for Mead for years 1995 (c) and $1996(d)$.

For 1995, the average observed yield for the three hybrids was $1336 \mathrm{~kg} / \mathrm{ha}$ and the corresponding average simulated yield was $1464 \mathrm{~kg} / \mathrm{ha}$ (Fig. 3 c). For 1996, the average observed and simulated yield values were 4241 and $4072 \mathrm{~kg} / \mathrm{ha}$, respectively (Fig. $3 d$ ). The average observed yield for the three hybrids for 1996 increased when compared to the average observed yield obtained for 1995. Average observed yield for three hybrids for the 2 years was $2788 \mathrm{~kg} / \mathrm{ha}$, while the average simulated yield was $2768 \mathrm{~kg} / \mathrm{ha}$. The RMSE for all three hybrids for the 2-year experiments was $542 \mathrm{~kg} / \mathrm{ha}$ and the value for $d$ was 0.97 . The above ground biomass at harvest was also accurately simulated and the $d$ value for the three hybrids for the 2-year experiment was $0 \cdot 92$.

\section{Planting date analysis for millet grown in Kollo, Niger}

The planting date analysis using 20 years of weather data (1982-2001) for Kollo showed that the best planting date for millet depends, in part, on the variety that will be used. The variety Heini Kirei had an extended period from planting to anthesis, which, on average, varied between 90 and 115 days (Fig. 4a) and also had a more prolonged grain filling period. The extended period of more than 100 days for Heini Kirei was simulated for the planting dates prior to 13 April. For the reproductive phase, the period from anthesis to physiological maturity was prolonged for the planting dates around 1 May for all three varieties. 

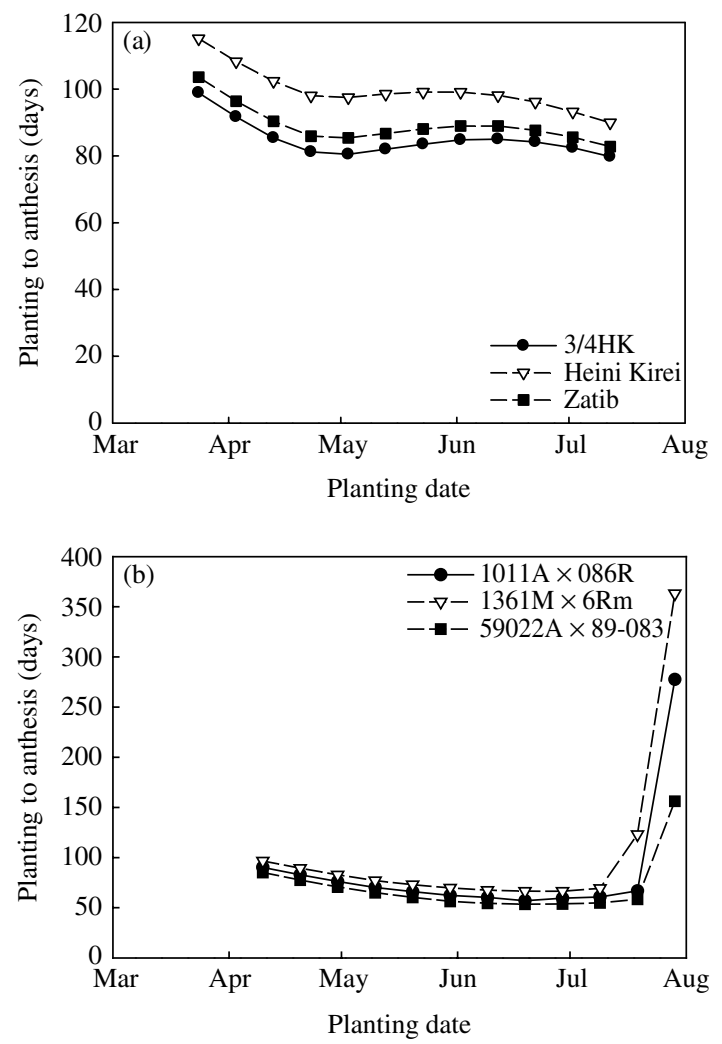

Fig. 4. Simulated number of days from planting to anthesis for different planting dates for millet grown in Kollo $(a)$ and Mead (b).

The statistical analysis (Tukey's test, $P<0.05$ ) of the simulated yield showed that for the variety Heini Kirei the planting dates between 13 and 23 May resulted, on average, in significant higher yields in comparison to the other planting dates. The simulated yields for these planting dates ranged from 1095 to $1247 \mathrm{~kg} / \mathrm{ha}$, respectively. However, a considerable variation between years was observed, as shown by the high standard deviations (Fig. 5a).

The duration from planting to anthesis for the varieties Zatib and 3/4HK ranged from 79 to 102 days (Fig. $4 a$ ). For the varieties that had shorter planting to anthesis and anthesis to grain filling periods, the planting dates that resulted in a high yield were somewhat later (Fig. 5a). The statistical analysis showed that for the varieties Zatib and 3/4HK, significant higher yields were, on average, simulated from 23 May to 2 June compared to the other planting dates. For early (March to 3 April) or late (July) planting dates, there was a distinct decrease in yield due to unfavourable weather conditions that occurred during certain periods of these planting dates. The simulations with and without fertilizer showed a similar response to varying the planting date (Figs $5 a$ and $5 b$ ).

The simulated total evapotranspiration for the entire season had the lowest values for the early planting dates and reached a maximum between 23 May and 12 June for all three varieties (Fig. 6). As expected, the longer the maturity of the variety, the higher the total evapotranspiration for the entire season. The highest total evapotranspiration was obtained for the variety Heini Kirei for the 2 June planting date $(262 \mathrm{~mm})$.

Usually, under water-limited conditions yield is correlated to evapotranspiration. The highest coefficient of determination between simulated yield and total evapotranspiration were found for the early planting dates, i.e. from 24 March to 23 April (Fig. 7). The lack of rains for the early planting dates (Fig. 1a) affected crop establishment and resulted in a severe reduction in yield. Also, the lack of rains during critical stages, especially around flowering and during grain filling, could be a cause for yield reduction. For the later planting dates after 13 May, there was a low coefficient of determination between simulated yield and total evapotranspiration. The lack of correlation between yield and evapotranspiration for the 13 May planting date (Fig. 7) can be explained because the yield for this planting date is mainly related to other environmental and management factors that are different from water, such as nutrient stress, as a smaller amount of $\mathrm{N}$ uptake was simulated for the entire growing season (data not shown). For the other later planting dates, the poor correlation could also be due to the fact that the critical stages to water stress are probably more exposed to water deficits, as these stages occur near the end of the rainy season. Consequently, the simulated yield was very low for many of the years, although the simulated total evapotranspiration was not low.

\section{Planting date analysis for millet grown in Mead, Nebraska}

For Mead, the simulated duration from planting to anthesis for the three hybrids (Fig. $4 b$ ) was greater for the early planting dates because of the low temperatures during the spring months in Mead that determined a low accumulation of degree days. This period is reduced from the early planting dates until the 29 June planting date; thereafter the simulated days to anthesis increased. For the reproductive phase from anthesis to physiological maturity, the April to 9 June planting dates had almost the same duration for each hybrid (around 30 days). For late planting dates in July, there was a clear increase in the number of days from anthesis to physiological maturity because of the low temperatures that normally occur during the 


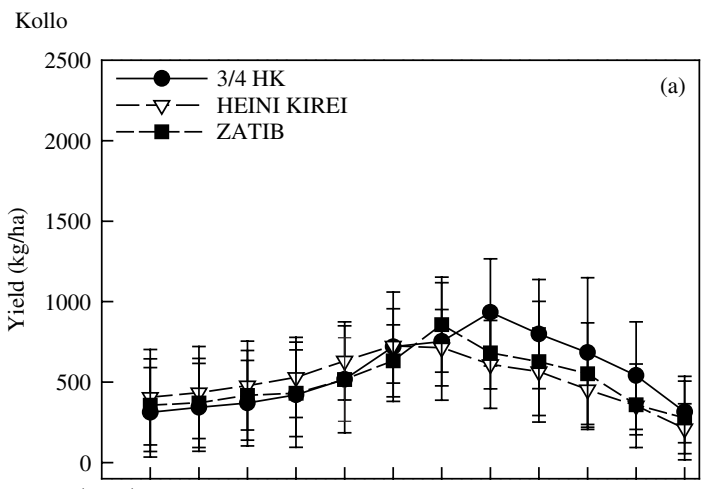

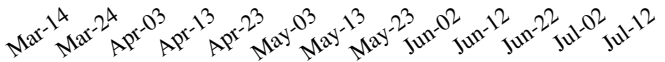

Planting date

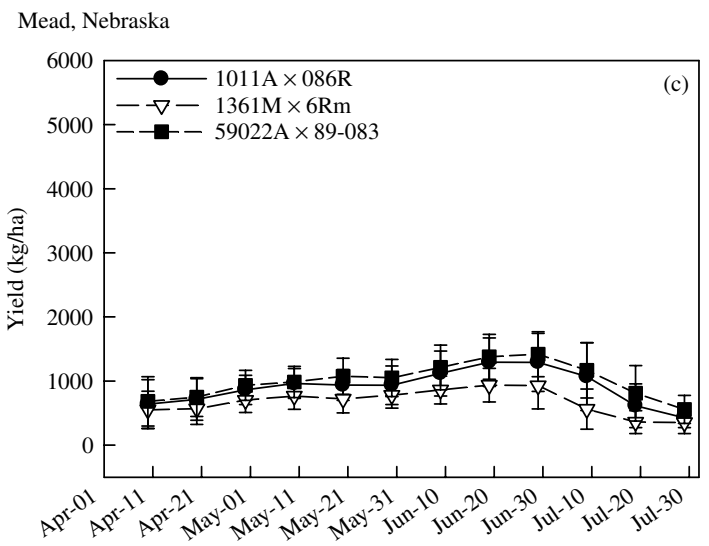

Planting date
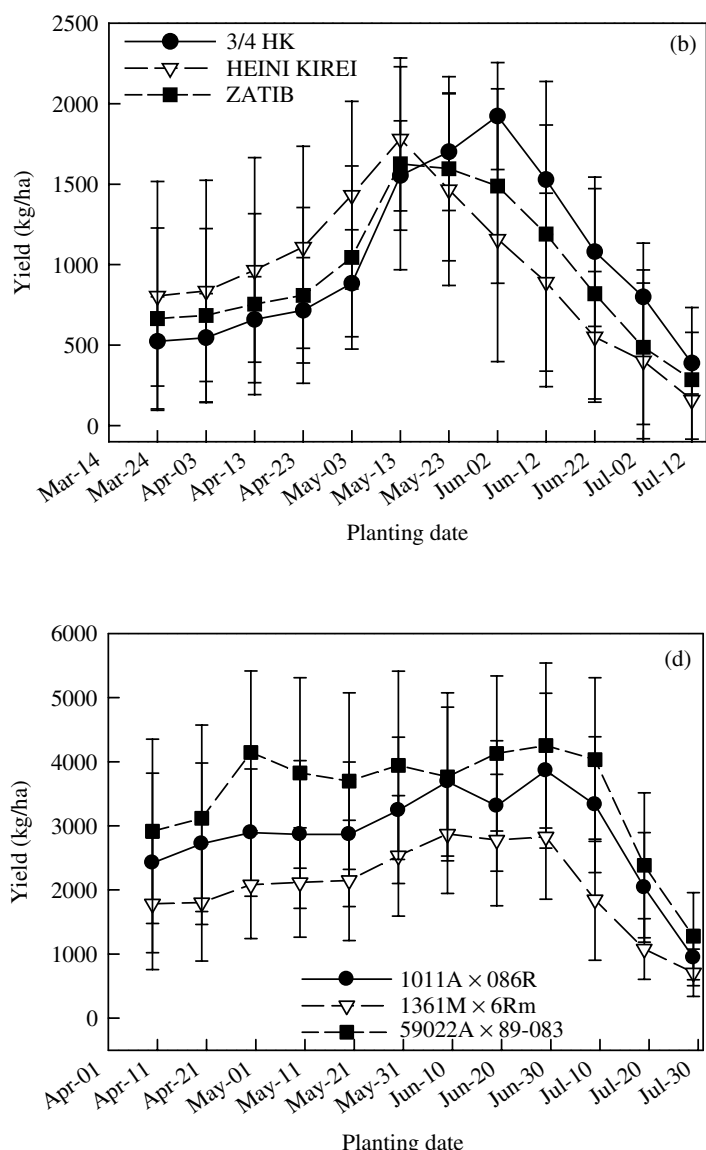

Fig. 5. Simulated millet yield for different planting dates for Kollo: without fertilizer (a); with fertilizer $(23 \mathrm{~kg} / \mathrm{ha}$ of $\mathrm{N})(b)$; and for Mead, Nebraska: without fertilizer $(c)$; with fertilizer $(78 \mathrm{~kg} / \mathrm{ha}$ of $\mathrm{N})(d)$.

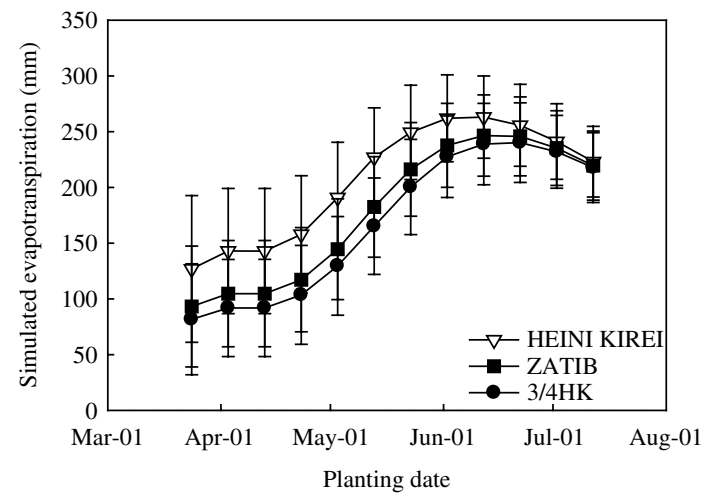

Fig. 6. Total crop evapotranspiration from planting to physiological maturity for different varieties in different planting dates for Kollo. autumn months (Fig. 1b), resulting in a lower accumulation of degree days.

For the hybrid $1361 \mathrm{M} \times 6 \mathrm{Rm}$ the duration from planting to anthesis was longer compared to the other two hybrids $(59022 \mathrm{~A} \times 89-083$ and $1011 \mathrm{~A} \times 086 \mathrm{R})$ for all planting dates (Fig. $4 b$ ). However, the shortest number of days from planting to anthesis was simulated for the 19 and 29 June planting dates, corresponding to a duration of 66 days for the $1361 \mathrm{M} \times$ $6 \mathrm{Rm}$ hybrid. The other two hybrids, 59022A $\times 89-083$ and $1011 \mathrm{~A} \times 086 \mathrm{R}$, also had the lowest number of days to anthesis for these two planting dates, i.e. 54 and 57 days, respectively. The planting date analysis using 35 years of weather records (1969-2003) showed that for the hybrid $1011 \mathrm{~A} \times 086 \mathrm{R}$ the 29 June planting date resulted, on average, in statistically significant high yields (Tukey test, $P \leqslant 0.05$ ) in comparison with the other planting dates (Fig. $5 c$ ). For 


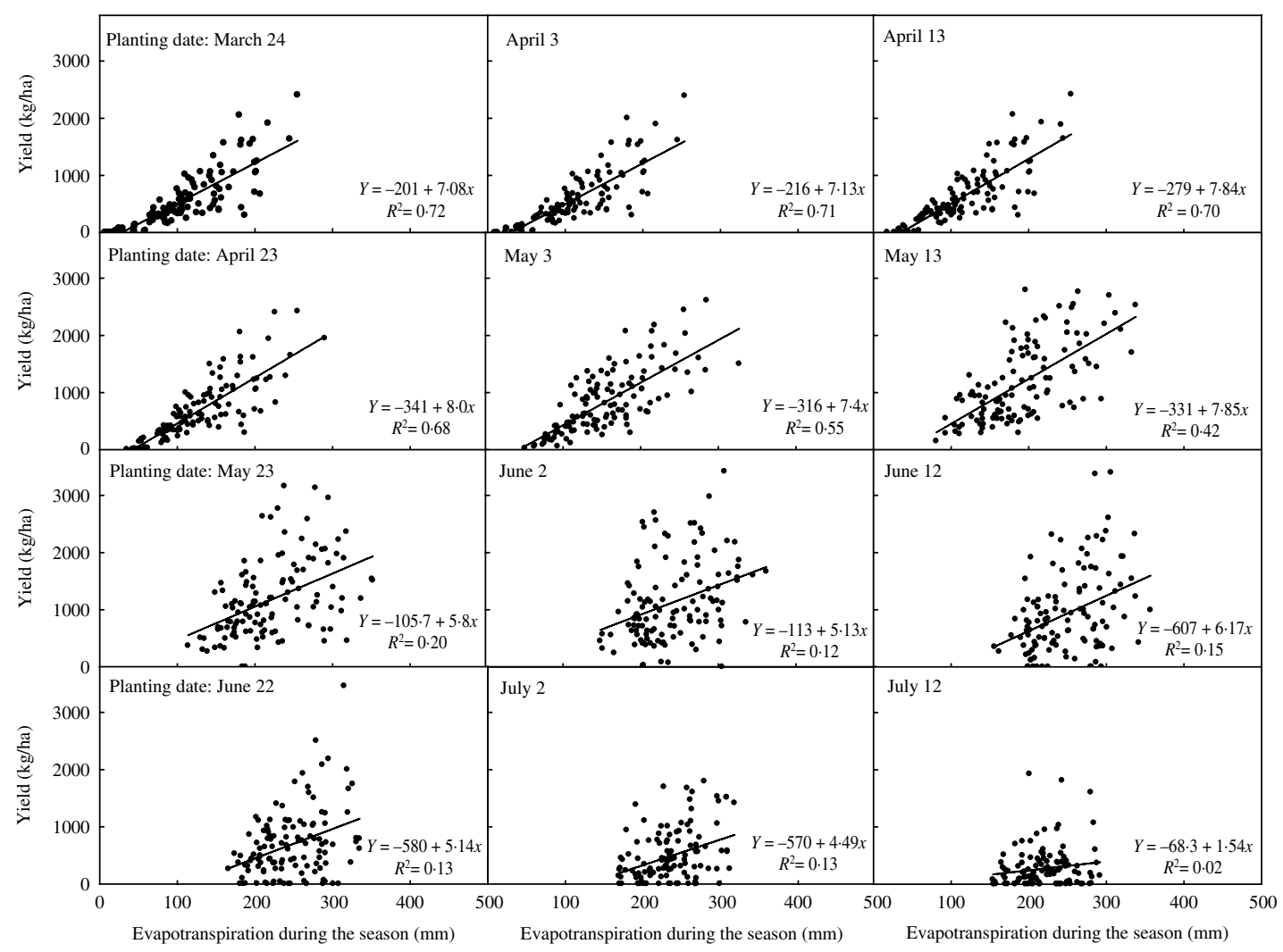

Fig. 7. Relation between simulated total evapotranspiration and millet yield for Kollo for the three varieties and different planting dates.

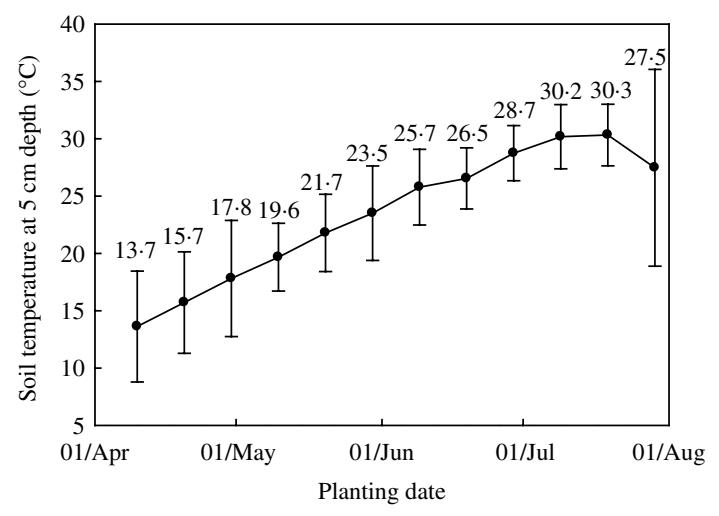

Fig. 8. Estimated average soil temperature (1969-2003) at a depth of $50 \mathrm{~mm}$ for different planting dates for Mead.

the hybrids $1361 \mathrm{M} \times 6 \mathrm{Rm}$ and $59022 \mathrm{~A} \times 89-083$ the best planting dates were, on average, between 19 and 29 June, with a statistically higher yield compared to the other planting dates. As an example, for the 19
June planting date, the average yield was $937 \mathrm{~kg} / \mathrm{ha}$ for the hybrid $1361 \mathrm{M} \times 6 \mathrm{Rm}$ and $1378 \mathrm{~kg} / \mathrm{ha}$ for the hybrid $59022 \mathrm{~A} \times 89-083$. When $78 \mathrm{~kg} / \mathrm{ha}$ of $\mathrm{N}$ was applied, the simulated yields increased considerably, but the optimum planting dates remained the same. For planting dates that were later than 9 July, there was a significant decrease in yield (Fig. $5 d$ ) for both the fertilized and non-fertilized systems. The analysis of the average soil temperature at a depth of $50 \mathrm{~mm}$ for the 35 years of weather records for the different planting dates (Fig. 8) showed an increase in soil temperature starting in April until 19 July. At the beginning of May, the average soil temperature was $18^{\circ} \mathrm{C}$ at a depth of $50 \mathrm{~mm}$; this is the recommended soil temperature for planting pearl millet (Andrews et al. 1998).

Total simulated evapotranspiration for the entire growing season showed decreased values for the late planting dates for all three hybrids and also showed a high value for standard deviation (Fig. 9). The coefficient of determination between total evapotranspiration and yield was somewhat high for only the early planting dates (Fig. 10). For the May and later 


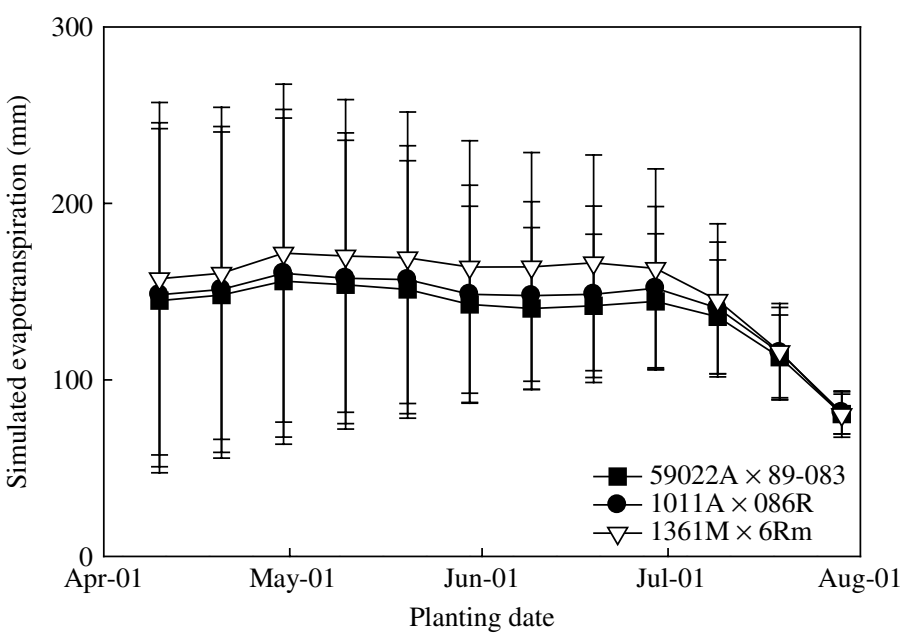

Fig. 9. Total crop evapotranspiration from planting to physiological maturity for different hybrids in different planting dates for Mead.

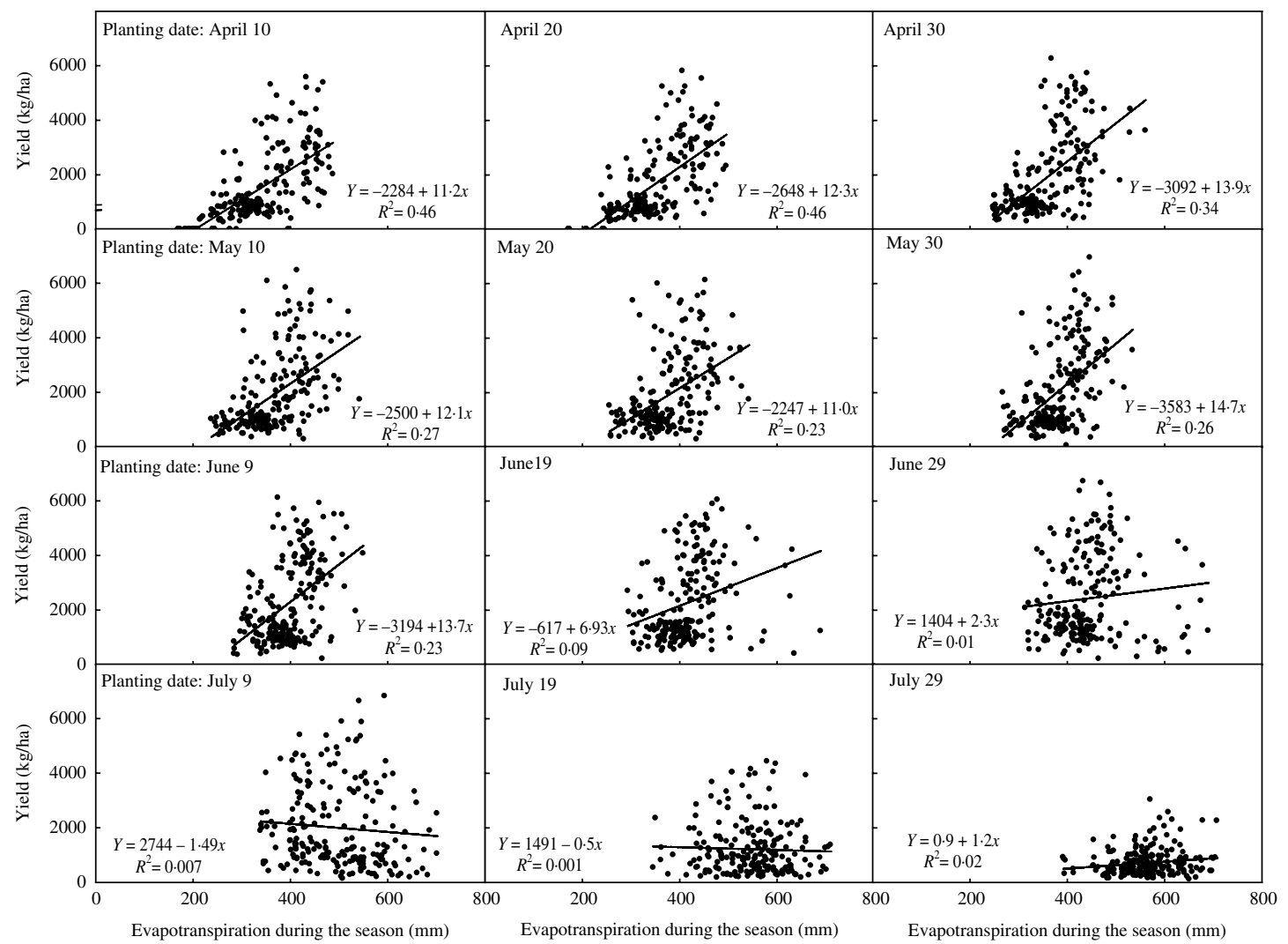

Fig. 10. Relation between simulated total evapotranspiration and millet yield for Mead, for the three hybrids and different planting dates. 
planting dates, $R^{2}$ was low, indicating that millet yield in Mead is not directly related to evapotranspiration, but more to other factors, such as the incidence of drought periods during critical stages and also in late planting dates the decrease in solar radiation and temperatures can negatively affect the crop grain yield.

\section{DISCUSSION}

The two contrasting environments of the present study were characterized by differences in some of the important weather variables and by different properties of the local soils. For the years 1995 and 1996, as well as for the long-term weather data, the rainfall in Kollo was evidently higher and the rainy season was more pronounced for the millet-growing season than the rainfall and rainy season in Nebraska (Figs $1 a$ and $1 b$ ). Also, for Kollo, higher temperatures were observed when compared to Mead, Nebraska.

There were differences in phenology due to the differences in planting dates and the genotypes used. For Kollo, the period from planting to anthesis ranged from 79 to 115 days. For the early planting dates, the number of days to maturity was extended, mainly due to response of millet to photoperiod and temperature. When it is exposed to photoperiods above $12 \mathrm{~h}$, the phasic development leading to panicle initiation is delayed (Reddy et al. 2004). Millet is a short-day crop that is sensitive to photoperiod, and this means that progress toward flowering is accelerated when day length decreases. For the reproductive phase, i.e. from anthesis to physiological maturity, the planting dates around 1 May resulted in a higher number of days to maturity for the three varieties.

The important differences found in the value of cultivar coefficient P2R for the different varieties grown in Kollo and hybrids grown in Mead, Nebraska are due to the fact that traditional cultivars of most tropical cereals depend on a strong sensitivity to photoperiod to regulate their time of flowering to match the environment of their origin (Vaksmann et al. 1996). Moving such germplasm to other latitudes, even within the tropics, results in flowering at inappropriate times for the new environments and increases the probability of drought, damage due to pests, diseases or birds and damage due to weather (Curtis 1968; Bonhomme et al. 1994). Extensive use of tropical germplasm in breeding programmes for subtropical or temperate latitudes usually requires conversion to a less day length-sensitive form that will flower in the desired time for the long-day environments of these latitudes.

For Mead, Nebraska, in 1996, abundant precipitation resulted in an increase in both observed and simulated yield when compared to 1995 . There were significant differences in yield between Mead and
Kollo, which can be attributed to several interrelated factors. One important factor to consider affecting the yield is the difference in soil properties, and particularly the difference in texture and acidity levels between the studied environments. For Kollo, the low yield potential of varieties planted by farmers, the poor soil fertility conditions as well as the low level of $\mathrm{N}$ that was applied and the low planting population used, can explain in part the low simulated yields. Furthermore, there are also other interrelated factors affecting the yield under real field conditions, such as crust-prone sandy soils with low fertility, combined with unreliable and erratic rainfall, that affect the spatial variability of crops grown in the Sahel (Rockstrom \& de Rouw 1997; Rockstrom et al. 1999).

Following the successful evaluation of the CSMCERES-Millet model for the two environments, the model was used for a planting date analysis. Other studies have shown that models can be rather useful for planting date analysis, compared to resource intensive experimental studies (Mavromatis et al. 2001; Saseendran et al. 2005). In relation to planting dates, farmers in Kollo usually plant long season varieties like Heini Kirei between the second week of May and the middle of June, depending upon the start of the rainy season. The shorter season varieties, Zatib and $3 / 4 \mathrm{HK}$ are normally planted later than Heini Kirei. Varieties such as Heini Kirei are promising especially for early and mid-season planting dates.

An important aspect of the planting date decision is not just based upon yield, but also minimizing the risk of failures of the plant stand establishment and the decrease in costs and labour required for replanting. This determines that, in general, local varieties are planted in an extended planting window that finishes during the middle of June. Although the CSMCERES-Millet does not consider some effects that could affect the actual yields, e.g. pests and diseases, the outcome of the present study still represents important scientific progress because of the scarcity of actual millet yield information from field experiments conducted at different planting dates.

M'Khaitir \& Vanderlip (1992) evaluated the performance of millet for several planting dates, ranging from mid-May to early July for two locations in Kansas (USA) and for 2 years. They found that the planting date had little impact on pearl millet yield for that particular environment. However, Pale et al. (2003) found that grain yield varied across the years for a planting date experiment conducted in Nebraska because of variable weather conditions. Pale et al. (2003) study did not show a clear relation between planting date and grain yield. The best planting date for pearl millet for one site and 1 year was on 15 May, while for another site the best planting dates were found between 7 June and 6 July for 2 years. Pale et al. (2003) suggested that pearl 
millet would be an interesting alternative for double cropping and/or late replanting situations in Nebraska. The present results from the planting date analysis showed that the highest average yield for the series of years was between 19 and 29 June; but with a wide window of acceptable planting dates depending on the selected hybrid. These planting dates can be considered late for a summer crop, confirming what previous studies indicated about the possibility of using pearl millet for replanting situations in Nebraska (Figs $5 c$ and $5 d$ ). However, at Mead, Nebraska, the planting period can be somewhat wide as shown in Figs $5 c$ and $5 d$, in which reasonable yields were simulated across a range of planting dates. At the beginning of May, the average soil temperature for the 35 years of climate record was $18{ }^{\circ} \mathrm{C}$ at a depth of $50 \mathrm{~mm}$. Thus, the results with respect to planting date recommendations for Mead, Nebraska based on the CSM-CERES-Millet model are in agreement with previous studies that suggest that for millet the appropriate soil temperature at planting time should be $18{ }^{\circ} \mathrm{C}$ (Andrews et al. 1998).

Evapotranspiration, defined as the water removed from soils by evaporation and plant transpiration, is directly related to yield for most cereals. A reduction in yield may occur when rainfall is insufficient to meet the evapotranspiration demand. Smaller plants transpire less water than larger ones because transpiration increases with an increase in leaf surface area (Cothren et al. 2000). In the present study, there were low values for the coefficient of determination between total simulated evapotranspiration for the growing season and millet yield grown in Kollo, for planting dates after 3 May. This indicated that there were other important factors that limited crop production and ultimately yield, besides water supply. These results agree with previous studies (Bley et al. 1991; Ravelo \& Planchuelo 1993), which found that crop water supply in parts of southwest Niger, in general, cannot be considered as the most limiting factor for millet production. Based on experiments conducted in Niger, Brück et al. (2000) found that pearl millet yield was reduced by $34 \%$ due to a low water supply and by $48 \%$ due to a low P supply. Payne (2000) found that for pearl millet with a sparse stand and leaf area index that was almost always less than two, the yield and evapotranspiration tended to be uncorrelated because evaporation constitutes a major portion of the evapotranspiration process. Under low-input conditions, pearl millet evapotranspiration is roughly one-third of that obtained under intensive management, suggesting that transpiration efficiency is also reduced by environmental stress, especially soil nutrient deficiency. Environmental stresses also cause poor root development, which results in reduction in potential crop water supply, and increased resistance to water uptake. Optimizing crop water use of sparse pearl millet stands will require some form of nutrient inputs (Payne 2000). Sivakumar \& Salaam (1999) found that under the harsh climatic conditions and sandy soils in Niger, nearly all plant-available water is used by the crop. Since evapotranspiration losses are largely controlled by the meteorological conditions, seasonal evapotranspiration is nearly the same whether yields are high or low.

In summary, the CSM-CERES-Millet model was able to simulate accurately growth, development and yield for millet grown in two contrasting environments, i.e. Mead and Kollo, and under different management practices that included various varieties/ hybrids and nitrogen fertilizer treatments. Following the evaluation of the model, it was also used to identify the optimum planting dates for different varieties grown in Kollo, and for different hybrids grown in Mead, Nebraska, and to assist in the explanation of potential yield reductions due to the interaction of planting date and local environmental conditions. In general, the results of the simulations confirmed previous field observations and showed the important role that crop simulation models can have in conducting systems analysis research. The planting date analysis using 20 years of climate records for Kollo indicated that the best planting dates, in part, depend on the variety that is going to be used. For varieties with physiological traits similar to Heini Kirei (maturity classification of 110-115 days to physiological maturity), the planting date to obtain the highest yield should be between 13 and 23 May, while for the varieties similar to Zatib (maturity classification of 95-105 days) and 3/4HK (maturity classification of 85-95 days) the planting dates should be, on average, somewhat later, between 23 May and 2 June. However, the starting date of the rainy season for the forthcoming growing season will affect a farmer's decision about the appropriate planting date. For Mead, Nebraska, the planting date analysis using 35 years of climate records showed that for hybrids $59022 \mathrm{~A} \times 89-083$ and $1361 \mathrm{M} \times 6 \mathrm{Rm}$, the highest simulated yield, on average, is obtained between 19 and 29 June. However, there was a wide window of potential planting dates without any significant difference in yield. For millet planted after 9 July, there was a significant decrease in simulated yields for all three hybrids. Further studies focused on evaluation and application of the millet model for other agroclimatic regions where pearl millet is an important crop are needed.

This work was supported in part by a grant from the U.S. Agency for International Development through the Sustainable Agriculture and Natural Resources Management Collaborative Research Support Program (SANREM-CRSP) and by State and Federal Funds allocated to Georgia Agricultural Experiment Stations Hatch Project GEO01654. 


\section{REFERENCES}

Amadou, M., Gandah, M., Bielders, C. L. \& Van Duivenbooden, N. (1999). Optimizing soil water use in Niger: research, development, and perspectives. In Efficient Soil Water Use-The Key to Sustainable Crop Production in Dry-Area Agriculture in West Asia, and North and Sub-Saharan Africa. Proceedings of the Workshops Organized by the Optimizing Soil Water Use (OSWU) Consortium, Niamey, Niger, 26-30 April 1998 and Amman, Jordan, 9-13 May 1998 (Eds N. Van Duivenbooden, M. Pala, C. Studer \& C. L. Bielders), pp. 143-164. Aleppo, Syria: ICARDA and ICRISAT.

Amato, S. V. \& Forrester, R. R. (1995). Evaluation of pearl millet as a feed ingredient for broiler rations. In Proceedings of the 1st National Grain Pearl Millet Symposium, Tifton, GA. 7-18 Jan. 1995 (Ed. I. D. Teare), pp. 125-128. Tifton, GA, USA: University of Georgia.

Andrews, D. J. \& Bramel-Cox, P. (1994). Breeding cultivars for sustainable crop production in low-input dryland agriculture in the tropics. In International Crop Science I (Ed. D. A. Buxton), pp. 211-222. Madison, WI, USA: CSSA.

Andrews, D. J., Rajewski, J. F. \& Kumar, K. A. (1993). Pearl millet: a new feed grain crop. In New Crops (Eds J. Janick \& J. Simon), pp. 198-208. New York: Wiley.

Andrews, D. J., Hanna, W. W., Rajewski, J. F. \& Collins, V. P. (1996). Advances in grain pearl millet: Utilization and production research. In Progress in New Crops (Ed. J. Janick), pp. 170-177. Alexandria, VA, USA: ASHS Press.

Andrews, D. J., Rajewski, J. F. \& Mason, S. C. (1998). Grain pearl millet: a new crop being developed at UNL. Extended Visions 2, 2-4.

Bacci, L., Cantini, C., Pierini, F., Maracchi, G. \& Reyniers, F. N. (1999). Effects of sowing date and nitrogen fertilization on growth, development and yield of a short day cultivar of millet (Pennisetum glaucum L.) in Mali. European Journal of Agronomy 10, 9-21.

Bationo, A., Christianson, C. B. \& Baethgen, W. E. (1990). Plant density and nitrogen fertilizer effects on pearl millet production in Niger. Agronomy Journal 82, 290-295.

Bationo, A. \& Ntare, B. R. (2000). Rotation and nitrogen fertilizer effects on pearl millet, cowpea and groundnut yield and soil chemical properties in a sandy soil in the semi-arid tropics, West Africa. Journal of Agricultural Science, Cambridge 134, 277-284.

Bley, J. \& Van Der Ploeg, R. R. (1991). A risk-probability map for millet production in southwest Niger. In Soil Water Balance in the Sudano-Sahelian Zone (Eds M. V. K. Sivakumar, J. F. Wallace, C. Renard \& C. Girou), pp. 571-581. Oxon, UK: Institute of Hydrology.

Bonhomme, R., Derieux, M. \& Edmeades, G. O. (1994). Flowering of diverse maize cultivars in relation to temperature and photoperiod in multilocational field trials. Crop Science 34, 156-164.

Brück, H., Payne, W. A. \& Sattelmacher, B. (2000). Effects of phosphorus and water supply on yield, transpirational water-use efficiency, and carbon isotope discrimination of pearl millet. Crop Science 40, 120-125.

Cothren, J. T., Matocha, J. E. \& Clark, L. E. (2000). Integrated crop management for sorghum. In Sorghum: Origin, History, Technology, and Production (Eds W. C.
Smith \& R. A. Frederiksen), pp. 409-441. New York: John Wiley \& Sons.

Curtis, D. L. (1968). The relation between yield and date of heading in Nigerian sorghums. Experimental Agriculture 4, 93-101.

FAOSTAT DATA. (2005). Available online at http://faostat. fao.org/site/340/DesktopDefault.aspx?PageID = 340 (verified 13/11/2007).

Fechter, J., Allison, B. E., Sivakumar, M. V. K., Verndplog, R. R. \& Bley, J. (1991). An evaluation of the SWATRER and CERES millet model for south-west Niger. In Soil Water Balance in the Sudano-Sahelian Zone (Eds M. V. K. Sivakumar, J. F. Wallace, C. Renard \& C. Girou), pp. 505-513. Oxon, UK: Institute of Hydrology.

Graef, F. \& Haigis, J. (2001). Spatial and temporal rainfall variability in the Sahel and its effects on farmers' management strategies. Journal of Arid Environments 48, 221-231.

Hanna, W. W. (1995). Breeding pearl millet for grain production. In Proceedings of the National Grain Pearl Millet Symposium, Tifton, GA. 17-18 Jan. 1995 (Ed. I. D. Teare), pp. 8-12.

Hoogenboom, G., Jones, J. W. \& Boote, K. J. (1992). Modeling growth, development, and yield of grain legumes using SOYGRO, PNUTGRO, and BEANGRO: a review. Transaction of the ASAE 35, 2043-2055.

Hoogenboom, G., Jones, J. W., Wilkens, P. W., Porter, C. H., Batchelor, W. D., Hunt, L. A., Boote, K. J., Singh, U., Uryaseva, O., Bowen, W. T., Gijsman, A. J., Du Toit, A. S., White, J. W. \& Tsuji, G. Y. (2004). Decision Support Systems for Agrotechnology Transfer Version 4.0. [CD-ROM]. Honolulu, HI: University of Hawaii.

Hunt, L. A., Parajasingham, S., Jones, J. W., Hoogenboom, G., Imamura, D. T. \& Ogoshi, R. M. (1993). Gencalc: software to facilitate the use of crop models for analyzing field experiments. Agronomy Journal 85, 1090-1094.

Jones, J. W., Mishoe, J. W. \& Boote, K. J. (1987). Introduction to Simulation and Modeling. Technical Bulletin 10. Florida, USA: ASPAC-Food and Fertilizer Technology Center.

Jones, J. W., Hoogenboom, G., Porter, C. H., Boote, K. J., Batchelor, W. D., Hunt, L. A., Wilkens, P. W., Singh, U., Gijsman, A. J. \& Ritchie, J. T. (2003). DSSAT cropping system model. European Journal of Agronomy 18, 235-265.

KathJu, S., Burman, U. \& Garg, B. K. (2001). Influence of nitrogen fertilization on water relations, photosynthesis, carbohydrate and nitrogen metabolism of diverse pearl millet genotypes under arid conditions. Journal of Agricultural Science, Cambridge 137, 307-318.

Loague, K. \& Green, R. E. (1991). Statistical and graphical methods for evaluating solute transport models: overview and application. Journal of Contaminant Hydrology 7, 51-73.

Maman, N., Mason, S. C., Galusha, T. \& Clegg, M. D. (1999). Hybrid and nitrogen influence on pearl millet production in Nebraska: yield, growth and nitrogen uptake, and nitrogen use efficiency. Agronomy Journal 91, $737-743$ 
Maman, N., Mason, S. C. \& Sirifi, S. (2000). Variety and management level influence on pearl millet production in Niger: I. Grain yield and dry matter accumulation. African Crop Science Journal 8, 25-34.

Mavromatis, T., Boote, K. J., Jones, J. W., Irmak, A., Shinde, D. \& Hoogenboom, G. (2001). Developing genetic coefficients for crop simulation models with data from crop performance trials. Crop Science 41, 40-51.

M'Khaitir, Y. O. \& VAnderlip, R. L. (1992). Grain sorghum and pearl millet response to date and rate of planting. Agronomy Journal 84, 579-582.

OnG, C. K. \& Monteith, J. L. (1985). Response of pearl millet to light and temperature. Field Crops Research 11, 141-160.

Pale, S., Mason, S. \& Galusha, T. D. (2003). Planting time for early-season pearl millet and grain sorghum in Nebraska. Agronomy Journal 95, 1047-1053.

Payne, W. A. (2000). Optimizing crop water use in sparse stands of pearl millet. Agronomy Journal 92, 808-814.

Ravelo, A. C. \& Planchuelo, A. M. (1993). Calibration of a Millet Simulation Model for Niger, Final Report. Niamey, Niger: AGRHYMET Center.

Reddy, N., Rao, K. \& Ahmed, I. (2004). Geographical patterns of diversity in pearl millet germplasm from Yemen. Genetic Resources and Crop Evolution 51, 513-517.

Ritchie, J. T. \& Alagarswamy, G. (1989). Simulation of sorghum and pearl millet phenology. In Modeling the Growth and Development of Sorghum and Pearl Millet (Eds S. M. Virmani, H. L. S. Tandon \& G. Alagarswamy), pp. 24-26. Research Bulletin No. 12. Patancheru, Andhra Pradesh, India: ICRISAT.

Ritchie, J. T., Singh, U., Godwin, D. C. \& Bowen, W. T. (1998). Cereal growth, development and yield. In Understanding Options for Agricultural Production (Eds G. Y. Tsuji, G. Hoogenboom \& P. K. Thornton), pp. 79-97. Dordrecht, The Netherlands: Kluwer Academic Publishers.

Rockstrom, J. \& de Rouw, A. (1997). Water, nutrients and slope position in on-farm millet cultivation in the Sahel. Plant and Soil 195, 311-327.

Rockstrom, J., Barron, J., Brouwer, J., Galle, S. \& DE Rouw, A. (1999). On-farm spatial and temporal variability of soil and water in pearl millet cultivation. Soil Science Society of America Journal 63, 1308-1319.

Ruiz-Nogueira, B., Boote, K. J. \& SAu, F. (2001). Calibration and use of CROPGRO-soybean model for improving soybean management under rainfed conditions. Agricultural Systems 68, 151-173.

SAS Institute. (2001). SAS System, 8th edn. Cary, NC, USA: SAS Institute.

Saseendran, S. A., Ma, L., Nielsen, D. C., Vigil, M. F. \& Ahuja, L. R. (2005). Simulating planting date effects on corn production using RZWQM and CERES-Maize models. Agronomy Journal 97, 58-71.

Sivakumar, M. V. K. (1988). Predicting rainy season potential from the onset of rains in southern Sahelian and Sudanian climatic zones of West Africa. Agricultural and Forest Meteorology 42, 295-305.

Sivakumar, M. V. K. \& SalaAm, S. A. (1999). Effect of year and fertilizer on water-use efficiency of pearl millet (Pennisetum glaucum) in Niger. Journal of Agricultural Science, Cambridge 132, 139-148.

Thornton, P. K., Bowen, W. T., Ravelo, A. C., Wilkens, P. W., Farmer, G., Brock, J. \& Brink, J. E. (1997). Estimating millet production for famine early warning: an application of crop simulation modelling using satellite and ground-based data in Burkina Faso. Agricultural and Forest Meteorology 83, 95-112.

Tsuji, G. Y., Jones, J. W., Hoogenboom, G., Hunt, L. A. \& Thornton, P. K. (1994). Introduction. In DSSAT v3, Decision Support System for Agrotechnology Transfer, vol. 1. (Eds G. Y. Tsuji, G. Uehara \& S. Balas), pp. 1-12. Honolulu, HI, USA: University of Hawaii.

Tsuji, G. Y., Uehara, G. \& Balas, S. (1998). DSSAT Version 3, vol. 4. Honolulu, HI, USA: University of Hawaii.

Vaksmann, M., Traore, S. B. \& Niangado, O. (1996). Le photopériodisme des sorghos Africains. Agriculture et Développement 9, 13-18.

Willmott, C. J., Ackleson, G. S., Davis, R. E., Feddema, J. J., KlinK, K. M., Legates, D. R., O'Donnell, J. \& Rowe, C. M. (1985). Statistics for the evaluation and comparison of models. Journal of Geophysical Research: Oceans 90, 8995-9005. 